\title{
Fine Mapping and Expression Analysis of Stripe Rust Resistance Genes derived from Aegilops geniculata
}

\author{
Shivendra Kumar*, Satinder Kaur, Parveen Chhuneja, \\ Mitaly Bansal and Indrajeet Singh Yadav
}

\author{
School of Agricultural Biotechnology Ludhiana (Punjab) 141004, India
}

*Corresponding author

\begin{tabular}{|l|}
\hline Ke y w o r d s \\
$\begin{array}{l}\text { Aegilops } \\
\text { geniculata, KASper } \\
\text { markers, } \\
\text { Introgression, SNP, } \\
\text { Stripe rust, Leaf } \\
\text { rust }\end{array}$ \\
\hline Article Info \\
\hline $\begin{array}{l}\text { Accepted: } \\
\text { 18 January } 2020 \\
\text { Available Online: } \\
\text { 10 February } 2020\end{array}$ \\
\hline
\end{tabular}

\section{A B S T R A C T}

Wheat production in temperate area is significantly affected by rust diseases, among which stripe (or yellow) rust caused by Puccinia striiformis Westend $\mathrm{f}$. sp. tritici and leaf (or brown) rust caused by Puccinia triticina Eriks. is major threat to production. Non-progenitor Aegilops species with substantial amount of variability for stripe rust resistance genes has been exploited to a limited extent. A tetraploid non-progenitor species (UUMM genome), namely Aegilops geniculata accession pau3549 is found to be resistant to stripe rust. A stripe rust resistant introgression line-ILT598 $\left(\mathrm{BC}_{2} \mathrm{~F}_{8}\right.$ Ae. geniculata acc. pau3549/CSS//3*WL711) was already available. In the present investigation an $\mathrm{F}_{5}$ population was derived from the cross of ILT598 with wheat cultivar WL711(NN). Inheritance studies in $\mathrm{F}_{5}$ population revealed that stripe rust resistance is controlled by a single dominant gene, temporarily designated as $\mathrm{YrAg}$. Mapping of $\mathrm{YrAg}$ was done by using SNP based KASper marker linked with two group of linked gene on chromosome 5DS viz Lr57-Yr40 and $\operatorname{Lr} 76-Y r 70$ and one marker was designed from candidate gene of comp_121307_c0_seq4 derived from ILT598. Molecular mapping using $\mathrm{F}_{5}$ population mapped $\mathrm{YrAg}$ at a distance of $3.3 \mathrm{cM}$ from $K A S P$ comp_121307_c0_seq4 towards distal end of chromosome 5D.

\section{Introduction}

Bread wheat (triticum aestivum 1. Thell, $2 n=42$ ) is a widely cultivated crop in India or worldwide and a potent source of nutrients. It occupies $17 \%$ of global crop area feeding about $40 \%$ of the world population (https://en.wikipedia.org/wiki/ international wheat production). It grows on 215 million hectares with global production stands at 739.5 million metric tons (CGAIR 2017), (FAOSTAT homepage; http://apps.fao.org) representing $19 \%$ of global cereal production with the world population is expected to grow from present 7.0 billion 9.0 billion by 2050 , India is the second largest wheat producer in the world and among the Indian states, Punjab is ranked second in wheat production after 
UtterPradesh. Stripe (yellow) rust (YR) caused by Puccinia striiformis f.sp. Tritici, is one of the major diseases of wheat in temperate regions also found in the tropics and subtropics. It infects leaves, leaf sheath and spikes of a wheat plant. This can infect barley, rye and more than 50 grass species also (Line 2002). The losses to wheat crop due to YR varies from 10-70 percent, depending upon the weather, races of pathogen, susceptibility of cultivar, and time of infection (Begum et al., 2014).

The regular use of limited parental genotypes in the advanced wheat breeding practices and monoculture of few improved wheat varieties results in a narrow genetic base in the cultivated wheat. Breakdown of mega variety PBW343 due to evolution of virulence against gene $\mathrm{Yr}_{27}$ is an example of pathogen evolution when a single variety is grown over large area (Prashar et al., 2007). New races of pathogen may develop through mutation or recombination of nuclei via a para-sexual process. Different YR genes includes seedling resistance or all time resistance genes Yr1.Yr2, Yr3, Yr4, Yr5, Yr6, Yr7, Yr8, Yr9, Yr10, Yr15, Yr17, Yr27 and adult plant resistance genes: $\operatorname{Yr} 11, \operatorname{Yr} 12, \operatorname{Yr} 13, \operatorname{Yr} 14$, Yr16, Yr18, Yr36, etc. (Mclntosh et al., 1995).

Fungicides are the only alternative to genetic resistance, their use increase the cost of production along-with increasing soil and water pollution and other pathogen resistance issue Thus, there is need to look for constant and diverse source of resistance. Therefore need to stack variable $\mathrm{R}$ genes instead of single $\mathrm{R}$ gene to induce the durable resistance. The germplasm of wild progenitor species consists huge reservoir of various resistance traits. This has led to inter-specific breeding for transferring preferred gene from wild progenitor into commercial cultivars (Knott 1981, Dvorak 1976, Stalker 1980, Dhaliwal et al., 1993).
To date more than 76 YR (Xiang et al., 2016) $\mathrm{R}$ gene have been categorized and almost half of these genes derived from their progenitor as well non-progenitor species. Evaluation of wild wheat germplasm at PAU for the past 20 years led to the identification of $\mathrm{C}, \mathrm{U}$, and $\mathrm{M}$ genomes from wild Triticum and Aegilops species as a potent resource for resistance to leaf and stripe rusts. Aegilops geniculata is a diploid $(2 n=42)$ non-progenitor species with UUMM genome. One of the accessions of Aegilops geniculata designated as pau3549 was resistant to stripe rust/yellow rust (YR) and leaf rust (LR). Phl mediated induced homeologous pairing resulted in transfer of $5 \mathrm{mgl}$ to chromosome 5D of wheat.

Initially a disomic substitution line DS5M (5D) have been developed and this line was crossed with a Chinese Spring (CS) stock carrying the Phl locus ( $P h l$ locus is responsible for homeologous recombination) (Chen et al., 1994). F1s from this cross were further crossed with WL711, a local variety susceptible to leaf rust and stripe rust (Aghaee-Sarbarzeh et al., 2002). One more backcross with WL711 and selfing of stable, leaf rust and stripe rust resistant plants with chromosome number $2 \mathrm{n}=42$ were carried forward and BC2F8 WL711-Ae.geniculata stable introgression lines (IL) were developed. Two of these IL were IL T598 (TA5601) and IL T756 (TA5602).

Molecular marker and GISH analysis of these two IL revealed the transfer of $5 \mathrm{mgl}$ to chromosome 5D of wheat. IL T756 has had the smaller fragment from Ae geniculata [T5DL·5DS-5mgs (0.95)] and is fully resistant to leaf rust while moderately resistant to stripe rust (40MS). Linked gene Lr57-Yr40 had already been mapped in IL T756 (Kuraparthy et al., 2008). IL T598 on other hand was completely resistant (0) to leaf rust as well as stripe rust with a larger fragment from Ae. Geniculata [T5DL.5DS- 
5mgs (0.75)] (Kurapathy et al., 2008). The present investigation was proposed with three objectives

1. Study genetics of stripe rust resistance genes in ILT598.

2. Molecular mapping of stripe rust resistance genes in ILT598.

Comparative gene expression analysis of stripe rust resistance in ILT756 (YR40) and ILT598.

\section{Materials and Methods}

The present investigation was performed at the experimental area and Molecular Biology Laboratory, School of Agricultural Biotechnology, Punjab Agricultural University, Ludhiana.

\section{Material}

Stripe rust resistant Wheat-Ae.geniculata introgression lines (IL) T598 (TA5601), ILT756 (TA5602) and susceptible cultivar WL711 NN=Non-Necrotic) were used as a parental line. $\mathrm{F}_{4}$ population derived from a cross of ILT598 with WL711(NN) and ILT756 respectively (leads to crosses).

\section{Methods}

The present investigation was carried out as three different experiments.

\section{Experiment 1}

Genetics of yellow rust resistance gene (s) transferred from Ae. geniculata in IL T598 (TA5601) (Kuraparthy. V et al., 2007).

Screening for Yellow rust resistance at the seedling stage

\section{Pathogen}

A single spore culture of Puccinia striformis tritici race 110S119 and 100S84 (pst) was used. Race $110 \mathrm{~S} 119$ is the most dominant race against stripe rust resistance responsible for knocking down of known gene. The cultures were obtained from Regional Station, Directorate of wheat research (DWR), Flowerdale, Shimla.

\section{Raising the seedlings and inoculation}

To raise the seedling of $\mathrm{BC} 2 \mathrm{~F} 4$ population displayed as WL711-introgression line (developed through crosses of introgression line T598 with WL711 (TA4325-152). The landrace 'WL711' was used as the susceptible check (initially WL711 has $\operatorname{Lr} 11$ and $\operatorname{Lr} 13$ in present scenario both of the leaf rust resistance gene $\operatorname{Lr} 11$ and $L r 13$ became recessive (Gupta AK et al., 1984)).

The seedlings were raised in glasshouse maintained at $18-20^{\circ} \mathrm{C}$ and $100 \%$ Relative humidity. The first leaf of seven days old seedlings was inoculated using spearhead needle with the homogenous urediniosporestalc mixture of yellow rust race 110S119 and 100S84 under above mentioned environmental condition.

\section{Scoring of infection types (IT)}

The infection types (ITs) were recorded 14 days after inoculation using the scale of Stakman et al., (1962) as shown in Table1. Seedlings with ITs, ranging from 0; and; were categorized as resistant and 3 as susceptible.

Screening of stripe rust resistance under field conditions (natural temp and relative humidity)

Stripe rust infection was recorded at the adult plant stage as the percentage of leaf area covered with rust urediospores, according to the stakman rule. 


\section{Statistical analysis}

The chi-square test will be used for testing goodness of fit of the data to the expected genetic Chi-square $\left(\chi^{2}\right)$ was applied to test goodness of fit of the expected ratios to the observed ones. Following expression was used for calculating chi-square values

$$
\chi^{2}(\mathrm{n}-1) \mathrm{d} . \mathrm{f}=(\mathrm{O}-\mathrm{E}) 2 / \mathrm{E}
$$

\section{Experiment 2}

Molecular mapping of yellow rust resistance genes using bulked segregant analysis.

\section{Isolation of genomic DNA and genotyping of the Ae.geniculata derived population}

Genomic DNA was isolated using CTAB method (Saghai Maroof et al., 1994) of 30 days old seedling leaf tissues were used collected from the field. DNA of all two $\mathrm{BC}_{2} \mathrm{~F}_{4}$ progenies along with advanced generation of $\mathrm{BC}_{2} \mathrm{~F}_{4}$ ((IL) T598* WL711 $(\mathrm{NN})$ )was $\mathrm{BC}_{2} \mathrm{~F}_{5}$. One of the $\mathrm{BC}_{2} \mathrm{~F}_{4}$ population was developed through a cross between introgression line (IL) $\mathrm{T} 598$ to cultivar WL711. Second $\mathrm{BC}_{2} \mathrm{~F}_{4}=$ ILT598*ILT756. Extracted sample were quantified using a NanoDrop® ND-1000 and ND-8000 8-Sample Spectrophotometers instrument

\section{KASP genotyping}

For KASP genotyping primer mix was prepared as per the recommendations by LGC Genomics by adding $46 \mu \mathrm{l} \mathrm{dH} 2 \mathrm{O}, 30 \mu \mathrm{l}$ common primer $(100 \mu \mathrm{M})$ and $12 \mu \mathrm{l}$ of each tailed primer of $100 \mu$ concentration. KASP genotyping assays were tested in 384-well format and each assay was set up as $4 \mu 1$ reactions $(2 \mu \mathrm{l}$ template DNA (final concentration of 20-30 ng of DNA), $1.944 \mu \mathrm{l}$ of $\mathrm{v} 42 \mathrm{x}$ KASP mix (LGC Genomics,
Teddington, UK), and $0.056 \mu$ primer mix). PCR was performed on a Eppendorf Master cycler pro 384 using the following temperature profile: hot start at $95^{\circ} \mathrm{C}$ for 15 $\mathrm{min}$, followed by ten touchdown cycles $\left(95^{\circ} \mathrm{C}\right.$ for $20 \mathrm{~s}$; touchdown at $65^{\circ} \mathrm{C}$ with $-1^{\circ} \mathrm{C}$ per cycle for $1 \mathrm{~min}$ ) then followed by 30 cycles of amplification $\left(94^{\circ} \mathrm{C} 20 \mathrm{~s} ; 57^{\circ} \mathrm{C} 1 \mathrm{~min}\right) .384-$ well optically clear plates (Cat. No. E10423000, Starlab) were read on a Tecan Safire plate reader. Fluorescence was visualized at a set temperature $37^{\circ} \mathrm{C}$. The fluorescence intensity scanning was then imported to KlusterCaller software (v 2.22.0.5, LGC Genomics) to check the cluster formation. If the defined genotyping clusters had not formed after the initial amplification, additional 5 to 10 amplification cycles were given in terms of add5, and the samples were scanned again. Further data analysis and scoring were performed manually using Klustercaller software.

KASP technology (a PCR based genotypic mechanism) was developed by LGC-Genomic and set a recommended standard KASP protocol. LGC-Genomic put standard with three well plate system respectively $96,384 \&$ 1542 well plate system.

\section{Primer designing}

We have RNA Seq data of ILs T598 and WL711 at six different time intervals $0 \mathrm{hr}$, $12 \mathrm{hr}, 24 \mathrm{hr}, 48 \mathrm{hr}, 72 \mathrm{hr}$ and $96 \mathrm{hr}$ (Yadav et al., 2016) all processes done in BIOINFORMATICS LAB school of agricultural biotech ludiana punjab. One of the genes selected ID comp_121307307_c0_seq4 was selected as it was NBS-LRR encoded and high confidence gene.

\section{Statistical analysis}

Mapping software MAPDISTO were used for 
computing the distance between the markers and trait (Lorieux 2007). The map was drawn using the programme MAPCHART version 2.1 developed by Voorips (2002).

\section{Experiment 3}

Expression analysis of candidate genes contributing towards yellow rust resistance.

Raising the seedlings, inoculation and sample collection

Seedlings of IL $\left(\mathrm{BC}_{2} \mathrm{~F}_{4}\right.$ generation) T598, IL T756, and a parental cultivar WL711(NN) were raised and first leaf of seven days old seedlings had infected with aYr race 110 S119 + talc. The inoculated seedling was incubated in a dark chamber maintained at $20^{\circ} \pm 1^{\circ} \mathrm{C}$ at $100 \%$ RH for 16h (Nayar et al., 1997).

Leaf samples were collected at different time interval of 0 hours, 6 hours, 12 hours, 24 hours, 48 hours 72 hours and 96 hours in three biological replicates followed by $14^{\text {th }}$ days rust appearance.

Total RNA extraction and c DNA conversion

Using Trizol manual method and RNA quantification done with $1.2 \%$ Denaturing gel based running gel unit. Prime Script ${ }^{\mathrm{TM}}$ first strand cDNA Synthesis Kit based cDNA Synthesis. c-DNA quantification using NanoDrop® ND-1000 and ND-8000 8Sample Spectrophotometers instrument

For RNA and c-DNA quantification OD value taken respectively 2.0 and 1.8 for expression analysis.

\section{Transcriptome analysis and identification} of candidate gene

Introgression line T598 and susceptible cultivar WL711 have been sequenced for RNA-Seq (cDNA) at six different time interval $0 \mathrm{hr}, 12 \mathrm{hr}, 24 \mathrm{hr}, 48 \mathrm{hr}, 72 \mathrm{hr}$ and $96 \mathrm{hr}$ (all RNA Seq data were generated from RNA which sample was inoculated with the 77-5 race of leaf rust) in another project. The reference Transcriptome Shotgun Assembly of WL711 submitted at GenBank (AC. GEWU00000000) was used as reference. The differentially expressed genes were investigated through using bioinformatic tools in SOAB-ludhiana and final candidate gene were investigated based on FPKM value (table: 7 and fig. 3) of expression over bar graph.

All five sequences related to comp121307_c0_seq4 gene sequence (candidate sequence out of 5 isolated sequence) were aligned and the SNPs identification had accomplished. Based on the SNPs site primer for KASP genotyping and QRT-PCR were designed. All primer designing has done with Vector-NTI Advanced software.

\section{Real-time quantitative RT-PCR}

Expression analysis using real-time quantitative PCR conduncted on the cDNA samples of IL T598, IL T756 and cultivar WL711 for six different time interval in triplicate The PCR amplification efficiency was determined for each primer combination by the slope of the standard curve obtained by plotting the fluorescence versus concentration of the individual cDNA of sample ILT598, ILT756, and cultivar WL711.

\section{Real-time quantitative PCR- assay}

Done all the QRT PCR reaction with LightCycler96 well plate qRT PCR (Roche). A total of 10 microliters of PCR reaction was performed at the School of Agricultural Biotechnology in wheat genomics lab. QRT- 
PCR reaction per performed with cDNA and two type of primer one was constitutive primer (Tubulin primer) and second was target primer (121307_c0_seq4) within the single white PCR Plate of 96-well, segmented, semi-skirted. Simultaneously a negative-template control (NTC) negative control was performed in same 96 PCR well plates. The pcr profile were used as intial denaturation at $94^{\circ} \mathrm{C} / 4 \mathrm{~min}$, denaturation at $94^{\circ} \mathrm{C} / 1 \mathrm{~min}$, annealing at $56^{\circ} \mathrm{C} / 1 \mathrm{~min}$ extension $72^{\circ} \mathrm{C} / 1 \mathrm{~min}$, and final elongation $94^{\circ} \mathrm{C} / 7 \mathrm{~min}$.

\section{Results and Discussion}

Inheritance of stripe rust resistance in ILT598 and WL711 against YR race 110s119 and 110s84 and list of Resistance, susceptible and homozygous in table: 1 \& 2

The segregation of 250 progenies in $F_{5}$ generation fit into 1.75HR: 0.5 Segr:1.75HS progenies with chi square value 4.4 indicating a single gene for YR resistance in ILT598. Since ILT598 is resistant at SS while WL711 is susceptible the YR resistance of ILT598 is due to seedling resistance gene also known as all-time resistance gene. Thus YR resistance of ILT598 is due to single resistance gene effective at all stage of plant growth. The gene was temporarily designated as $\mathrm{YrAg}$.

\section{Mapping of stripe rust resistance gene}

Selection of markers for mapping of YR resistance

Linked LR and YR and genes have already been reported on chromosome 5DS Lr57/Yr40 from Ae. geniculata (Kuraparthy et al., 2007) in ILT756, a sister line of T598.Another linked geneLr76/Yr70from Ae. Umbellulata have also been mapped on chromosome 5DS (Bansal et al., 2017). The SNP markers for both pair of genes reported by Kuraparthy et al., (2016) and Bansal et al., (2017) were selected initially with the hypothesis that ILT598 also has YR gene on the chromosome 5DS. Thus 41SNP markers have been selected of which 9 markers reported to be linked with Lr57-Yr40and 33 markers have been linked with Lr76-Yr70 (Table: 3). Another new marker has been designed from candidate gene sequence derived from RNA sequence data of IL-T598 (candidate gene sequence from RNA extracted after inoculation with leaf rust pathogen) in table: 4 .

\section{Selection of candidate gene}

Possible candidate R-gene transcripts were selected, which have homologs on chromosome 5DS, as resistance gene in an another IL-T756 was previously mapped short arm of chromosome 5D (Kuraparthy et al., 2008). Finally we identified six R-genes mapping to chromosome 5DS, filtered on the basis of maximum percent identity $>99 \%$ and $>98 \%$ query coverage. FPKM (Fragments PerKilobase of transcript per Million mapped reads) values of these mapped transcripts were extracted for both WL711 and ILT598 at 6 time intervals and were averaged for replicates. One R-gene (named comp_121307_c0_seq4) transcript demonstrating consistent expression in term of FPKM values was selected.

\section{Genotyping of $\mathrm{F}_{5}$ population}

The selected 42 selected markers from chromosome 5DS were amplified on parental lines ILT598 and WL711, of which nine were found to be polymorphic including one marker linked toLr57/Yr40, seven markers linked to $L r 76 / Y r 70$ and one marker from selected candidate gene from 5DS. These nine markers were further amplified on the 250 $\mathrm{F}_{5}$ progenies. The entire 9 marker found to be associated with $\mathrm{YrAg}$ gene leading to formation of linkage map of $7.72 \mathrm{cM}$ with KASP marker comp_121307_c0_seq4 being 
closest at a distance of 3.3cM (Fig 1). All the markers were scored as co-dominant markers with "A" given to susceptible WL711 allele, "B" given to resistant ILT598 allele and " $H$ " given to progenies amplifying both the resistant and susceptible alleles in fig 2 . Segregation of three alleles in $\mathrm{F}_{5}$ population is given in Table: 5 .

\section{Validation of candidate gene using qRT- PCR}

The real-time PCR has been performed to validate the time a specific level of transcription of a leaf rust resistance and stripe rust in the fig. Resistance genes respectively. Samples were collected from two resistants IL T598 and T756 and one susceptible cultivar WL711 at six different time intervals after the inoculation with respective pathogen. Real time PCR primers have been designed from candidate gene comp_121307_c0_seq4.

\section{Expression analysis report for validation of} comp_121307_c0_seq4 using QRT-PCR

qRT-PCR was done for real-time expression analysis, among leaf samples of at six different time interval $(0,12,24,48,72$ and $96 \mathrm{hr}$ after leaf rust and stripe rust inoculations). Samples were collected in the month of November 2017 in RNA later solution. Validation of the candidate reference gene comp_1231307_c0_seq4 qRT-PCR was done in School of Agricultural Biotechnology (SOAB) Ludhiana (Wheat Molecular Biotechnology Lab). For a successful qRTreal-time experiment, housekeeping gene alpha-Tubulin was used as internal control among the most commonly used reference gene for wheat (Teneaet al., 2011).

Expression profile for
comp_121307_c0_seq4

The expression of candidate comp_121307_c0_seq4gene relative to an alpha-tubulin gene in stressed plants was determined using $2^{-\Delta \Delta C T}$ method (Livak and Schmittgen 2001). Using $2^{-\Delta \Delta C T}$ method, the fold change in candidate121307_c0_seq4gene expression for different time interval transcript normalized to tubulin gene and related to the mock plants was determined.

Relative changes depict in terms of threshold cycle (CQ) value. It has been used for detection of expression level.

$\mathrm{Cq}$ value is the amplification cycle number over which fluorescent signal reached above the baseline. Baseline level has been standardized to mean. A CQ value will be inversely proportional to the level of expression (Zhi et al., 2016). The expression profile of wheat developmental stage was investigated by candidate gene comp_121307_c0_seq4, which depicts the level of expression for all three parental line IL T598, IL T756 and WL711. The expression profile reveals the concept of the candidature of gene for leaf rust and stripe rust resistance.

Expression analysis of comp_121307_c0_seq4 gene after leaf rust inoculations

Relative gene expression was calculated in three ILT598, ILT756 and WL711 at six different time interval as shown in Table: 9. In IL-T598, IL-T756 and susceptible cv.WL711 the transcripts of gene comp_121307_c0_seq4 were detectable at all six different time intervals.

Resulted fold expression were shoot up to a higher level in IL T598 and maximum 5.4041 at $24 \mathrm{hr}$, subsequently hypersensitive response decreases simultaneously relatively fold expression fall down to 1.652. Similarly for IL T756 relative fold expression were observed maximum 2.10 at $12 \mathrm{hr}$, further 
declined 1.22 at $24 \mathrm{hr}$ and 0.732 at $48 \mathrm{hr}$. In WL711 relative fold expression has been observed 0.335 almost throughout the all six different time interval. The elevated pattern of increase in expression of comp_121307_c0_seq4 was noticed at 24hr for IL T598, at $12 \mathrm{hr}$ for IL T756 shown in fig 4. The results showed a higher expression of leaf rust resistance gene from ILT598 as compared to ILT756 indicating a different R gene controlling the resistance in both the introgression lines.

Inheritance of stripe rust resistance in ILT598 and WL711 against YR race 110s119 and 110s84 and list of Resistance, susceptible and homozygous in table: $1 \& 2$.

Table.1

\begin{tabular}{|l|l|l|l|}
\hline S.No & STAGE & ILT598 & WL711 \\
\hline 1 & SEEDLING STAGE $($ SS $)$ & $; 1$ & $3-3+$ \\
\hline 2 & ADULT & $0-T R$ & $60 S-80 S$ \\
\hline
\end{tabular}

Table.2

\begin{tabular}{|c|c|c|c|}
\hline S.No & $\begin{array}{l}\text { RESISTANCE } \\
\text { 20MR) }\end{array}$ & $\begin{array}{l}\text { SUSCEPTIBLE(20S- } \\
\text { 60S) }\end{array}$ & $\begin{array}{l}\text { HOMOZYGOUS(TR- } \\
\text { 40S) }\end{array}$ \\
\hline 1 & 120 & 109 & 19 \\
\hline
\end{tabular}

Table.3 KASP markers specific to alien introgression on chromosome 5DS

\begin{tabular}{|c|c|c|c|c|c|}
\hline $\begin{array}{l}\text { S. } \\
\text { No. }\end{array}$ & $\begin{array}{l}\text { Source of SNP } \\
\text { markers }\end{array}$ & $\begin{array}{c}\text { Non-progenitor } \\
\text { involved in } \\
\text { introgression/genome } \\
\text { introgressed on } \\
\text { chromosome 5DS }\end{array}$ & $\begin{array}{c}\text { No. of } \\
\text { markers } \\
\text { applied to } \\
\text { the } F_{2} \\
\text { population }\end{array}$ & $\begin{array}{c}\text { Number of } \\
\text { polymorphic } \\
\text { markers }\end{array}$ & $\begin{array}{l}\text { Polymorphic } \\
\text { KASP } \\
\text { markers }\end{array}$ \\
\hline 1 & $\begin{array}{l}\text { Lr57/Yr4O(IL-T756) } \\
\text { (Tiwari et al., 2015) }\end{array}$ & $\begin{array}{c}\text { Aegilops } \\
\text { geniculata/UUMM }\end{array}$ & 9 & 1 & KASP3 \\
\hline 2 & $\begin{array}{c}\text { Lr76/Yr70 } \\
\text { (Bansal } \text { et al., 2017) }\end{array}$ & $\begin{array}{c}\text { Aegilops } \\
\text { umbellulata/UU }\end{array}$ & 33 & 7 & $\begin{array}{c}\text { KASP178 } \\
\text { (Plate3), } \\
\text { KASP71, } \\
\text { KASP119, } \\
\text { KASP217, } \\
\text { KASP221, } \\
\text { KASP228, } \\
\text { KASP117 }\end{array}$ \\
\hline 3 & $\begin{array}{c}\text { Gene ID } \\
\text { comp_121307_c0_seq4 } \\
\begin{array}{c}\text { (IL-T598) } \\
\text { (IL-Te }\end{array}\end{array}$ & $\begin{array}{c}\text { Aegilops } \\
\text { geniculata/UUMM }\end{array}$ & 1 & 1 & KASP1 \\
\hline & Total & & 42 & 9 & \\
\hline
\end{tabular}


Table.4 Sequence of different KASP markers used for mapping of YR resistance gene in ILT598in present study KASP_121307307_c0_seq4 information

\begin{tabular}{|c|c|c|}
\hline S. No & Primer & Sequence \\
\hline $\mathbf{1}$ & Lr57_cds_kasp1_FAM & GAAGGTGACCAAGTTCATGCTTTTTGGACCTgGCATGGAATAAGC \\
\hline $\mathbf{2}$ & Lr57_cds_kasp1_HEX & GAAGGTCGGAGTCAACGGATTTTTTGGACCTgGCATGGAATAAGT \\
\hline $\mathbf{3}$ & Lr57_cds_kasp1_COM & AGATTCCTGAGCCTTGTTACTTCGG \\
\hline
\end{tabular}

Table.5 Segregation of different alleles in selected polymorphic KASP markers in $\mathrm{F}_{5}$ population derived from T598X WL711

\begin{tabular}{|c|c|c|c|c|}
\hline \multirow{2}{*}{ Marker } & \multicolumn{3}{|c|}{ F Population } & Chi Square \\
\cline { 2 - 4 } & B & H & A & value \\
\hline Lr76/Yr70_KASP1 & 94 & 34 & 122 & 3.86 \\
\hline Lr57/Yr40_KASP3 & 126 & 0 & 125 & 35.9 \\
\hline Lr76/Yr70_KASP117 & 92 & 35 & 122 & 4.68 \\
\hline Lr76/Yr70_KASP119 & 94 & 29 & 121 & 3.5 \\
\hline Lr76/Yr70_KASP178 & 96 & 32 & 121 & 2.9 \\
\hline Lr76/Yr70_KASP221 & 96 & 31 & 123 & 3.33 \\
\hline Lr76/Yr70_KASP228 & 94 & 32 & 117 & 2.59 \\
\hline Lr76/Yr70_KASP71 & 94 & 32 & 117 & 2.59 \\
\hline Lr76/Yr70_KASP217 & 93 & 26 & 127 & 6.21 \\
\hline COMP_121307_CO_SEQ4 & 90 & 33 & 117 & 3.81 \\
\hline
\end{tabular}

All the selected KASP markers segregated in expected ratio of $1.75 \mathrm{HR}: 0.5 \mathrm{segr} .1 .5 \mathrm{HS}$, except marker Lr57/Yr40_KASP3 which showed segregation distortion with no heterozygous progenies (table5).

\section{Expression analysis of comp_121307_c0_seq4 gene after stripe rust inoculation}

The transcripts of comp_121307_c0_seq4 gene were detectable at all six different time intervals. There was increase in fold expression in IL T598 and maximum 1.077 at 24hr,(Table: 10) subsequently hypersensitive response decreases simultaneously relatively fold expression fall down to 0.246 at $48 \mathrm{hr}$. In IL T756 relative fold expression were observed maximum 10.65 at $12 \mathrm{hr}$, further declined 1.14 at $24 \mathrm{hr}$ and 0.695 at $48 \mathrm{hr}$. In susceptible cultivarWL711 relative fold expression has been observed 0.335 almost throughout the all six different time interval.

The elevated pattern of increase in expression of comp_121307_c0_seq4 was noticed at $24 \mathrm{hr}$ for IL T598, for IL T756 it was maximum at $12 \mathrm{hr}$ and in case of WL711 gene expression at baseline shown in fig 5. qRT-PCR results showed that might be different alleles of stripe rust resistance gene will be responsible for abrupt fold change (10.65) in T756 than in T598.gene). In T598 the expression of leaf rust and stripe rust transcript increases to maximum $24 \mathrm{hr}$ after inoculation while in ILT756 maximum transcript were raised after $12 \mathrm{hr}$ of inoculation indicating a separate mechanism of expression in both the introgression lines derived from same source. 
Table.6 Details of six candidate genes identified from RNA sample taken at six different time interval in IL-T598

\begin{tabular}{|c|c|c|c|c|c|c|c|}
\hline S.No. & Ids & Chr & $\begin{array}{c}\text { \% } \\
\text { identity }\end{array}$ & $\begin{array}{c}\text { Alignment } \\
\text { length }\end{array}$ & Q start & Q end & $\begin{array}{c}\text { End } \\
\text { point }\end{array}$ \\
\hline $\mathbf{1}$ & Comp_44675_c0_seq1 & chr5D & 100 & 482 & 555065344 & 555065825 & 891 \\
\hline $\mathbf{2}$ & Comp_92855_c0_seq2 & chr5D & 100 & 1839 & 555050581 & 555048743 & 3397 \\
\hline $\mathbf{3}$ & Comp_110328_c0_seq1 & chr5D & 99.889 & 2700 & 555046066 & 555048765 & 4968 \\
\hline $\mathbf{4}$ & Comp_113501_c0_seq1 & chr5D & 99.92 & 2493 & 193130396 & 193132887 & 4591 \\
\hline $\mathbf{5}$ & Comp_114926_c1_seq1 & chr5D & 99.599 & 2493 & 193132887 & 193130396 & 4547 \\
\hline $\mathbf{6}$ & Comp_121307_c0_seq4 & chr5D & 99.517 & 2279 & 28483925 & 28481647 & 4148 \\
\hline
\end{tabular}

Table.7 Mean FPKM value of comp121307_c0_seq4 of all 6 different time intervals

\begin{tabular}{|c|c|c|c|}
\hline S.No. & Time interval & IL T598 & WL711 \\
\hline 1 & $0 \mathrm{hr}$ & 0.176667 & 0.38 \\
\hline 2 & $12 \mathrm{hr}$ & 0.845 & 0.09333 \\
\hline 3 & $24 \mathrm{hr}$ & 0.58 & 0.25667 \\
\hline 4 & $48 \mathrm{hr}$ & 0.055 & 0.66333 \\
\hline 5 & $72 \mathrm{hr}$ & 0.375 & 0.30667 \\
\hline 6 & $96 \mathrm{hr}$ & 2.09 & 1.23 \\
\hline
\end{tabular}

Table.8 Primer information for RT-PCR

\begin{tabular}{|c|c|c|c|}
\hline S.No & primer & Gene sequence & Tm value $\left({ }^{0} \mathrm{C}\right)$ \\
\hline \multirow[t]{2}{*}{1} & Alpha tubulin F & 5'AGGAGGATGCAGCCAACAAC3' & \multirow[t]{2}{*}{58} \\
\hline & Alpha-tubulin R & 5'AGGGCCAGAGCCAGTTCCA3' & \\
\hline \multirow[t]{2}{*}{2} & Lr57_cds_RT_F & 5'AGATTCCTGAGCCTTGTTACTTCGG3' & \multirow[t]{2}{*}{58} \\
\hline & Lr57_cds_RT_R & 5’TAAGCTGTCgGGAAGATTGCCTAC3' & \\
\hline
\end{tabular}

Table.9 Relative change in fold expression of candidate comp_121307_c0_seq4 for leaf rust infected transcript

\begin{tabular}{|c|c|c|c|}
\hline ILS/Time interval & ILT598 & ILT756 & WL711 \\
\hline 0HR & 1 & 1 & 1 \\
\hline 12HR & 1.153672 & 2.109344 & 0.332754 \\
\hline $\mathbf{2 4 H R}$ & 5.404151 & 1.220928 & 0.029429 \\
\hline $\mathbf{4 8 H R}$ & 1.652991 & 0.732692 & 0.335372 \\
\hline $\mathbf{7 2 H R}$ & 0.059284 & 0.011861 & 0.000744 \\
\hline 96HR & 0.007882 & 0.000829 & 0.000196 \\
\hline
\end{tabular}


Table.10 Relative change in fold expression of candidate comp_121307_c0_seq4 for Stripe rust infected transcript

\begin{tabular}{|c|c|c|c|}
\hline ILS/Time interval & ILT598 & ILT756 & WL711 \\
\hline 0HR & 1 & 1 & 1 \\
\hline 12HR & 0.9338787 & 10.656887 & 0.613007 \\
\hline $\mathbf{2 4 H R}$ & 1.0779788 & 1.1426095 & 0.108814 \\
\hline $\mathbf{4 8 H R}$ & 0.2467669 & 0.6954796 & 0.215301 \\
\hline $\mathbf{7 2 H R}$ & 0.1178811 & 0.2168354 & 0.015147 \\
\hline $\mathbf{9 6 H R}$ & 0.0772041 & 0.2431148 & 0.066347 \\
\hline
\end{tabular}

$5 \mathrm{D}$

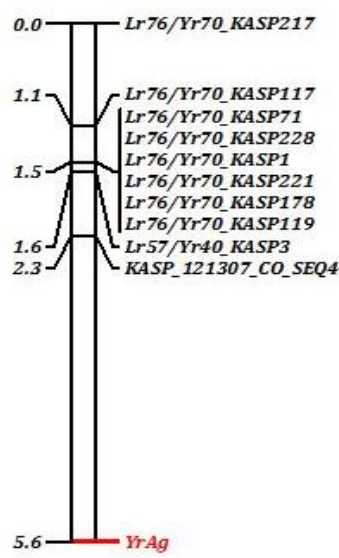

Fig.1 Partial linkage map of homoeologous group 5 carrying an introgressed segment with stripe rust resistance gene ( $\mathrm{rAg}$ ) from Ae geniculata acc pau 3549 based on $\mathrm{F}_{5}$ population derived from a cross wheat-Ae. geniculata ILT598*WL711

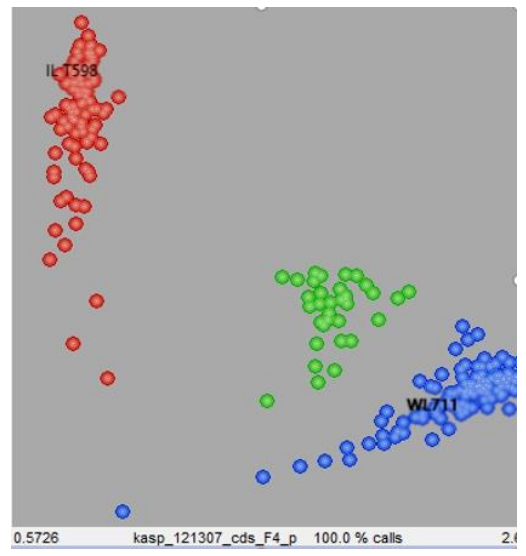

Fig.2 Kompetitive allele specific polymorphic (KASP) marker quantification kasp_121307_c0_seq4 investigate the resistant and susceptible parents and selected progenies of F5 population derived from Ae. Geniculata, blue susceptible, red resistant progenies and green is homozygous which is highlighted in figure 


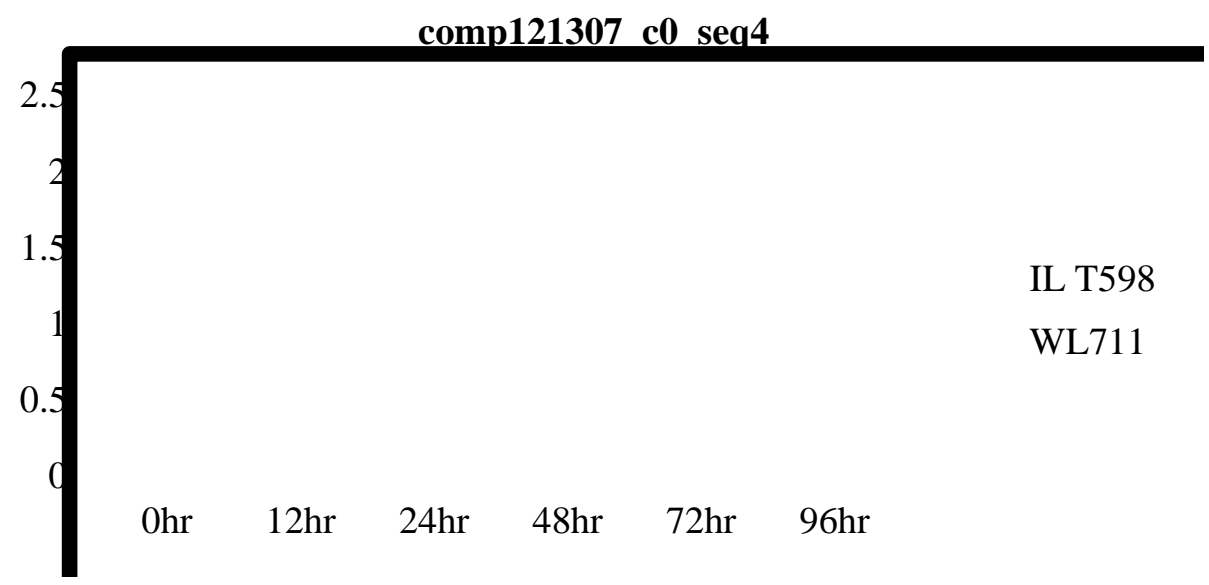

Fig.3 Comp121307_c0_seq4 FPKM value analysis

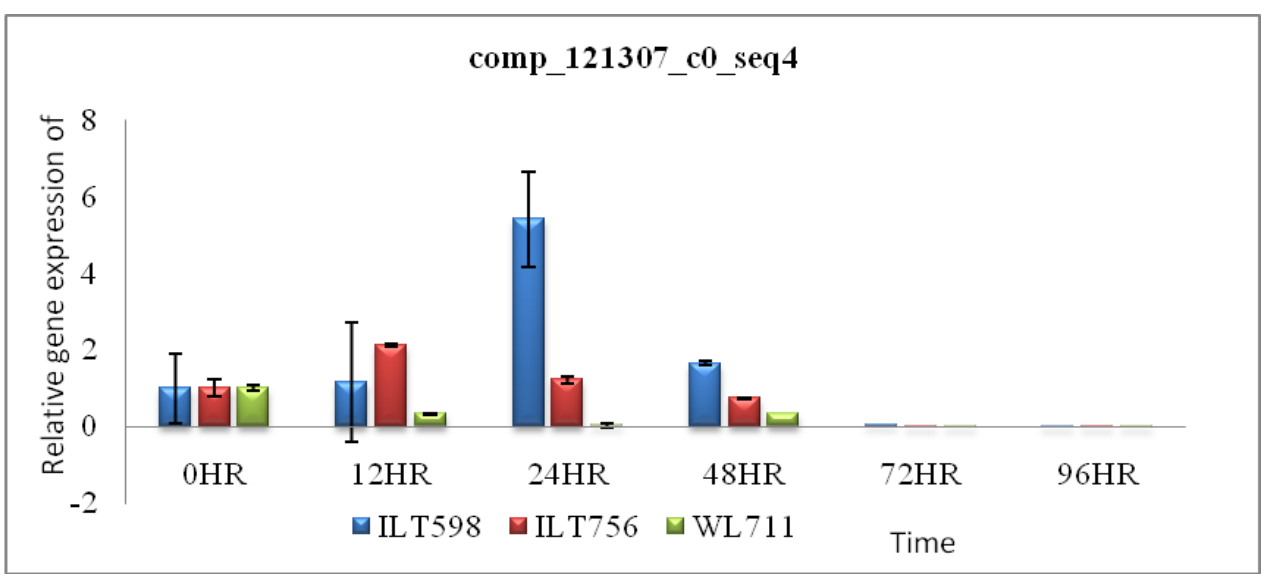

Fig.4 Gene folds expression (for leaf rust inoculated) at six different time interval in three parental lines IL T598, IL T756, and WL711

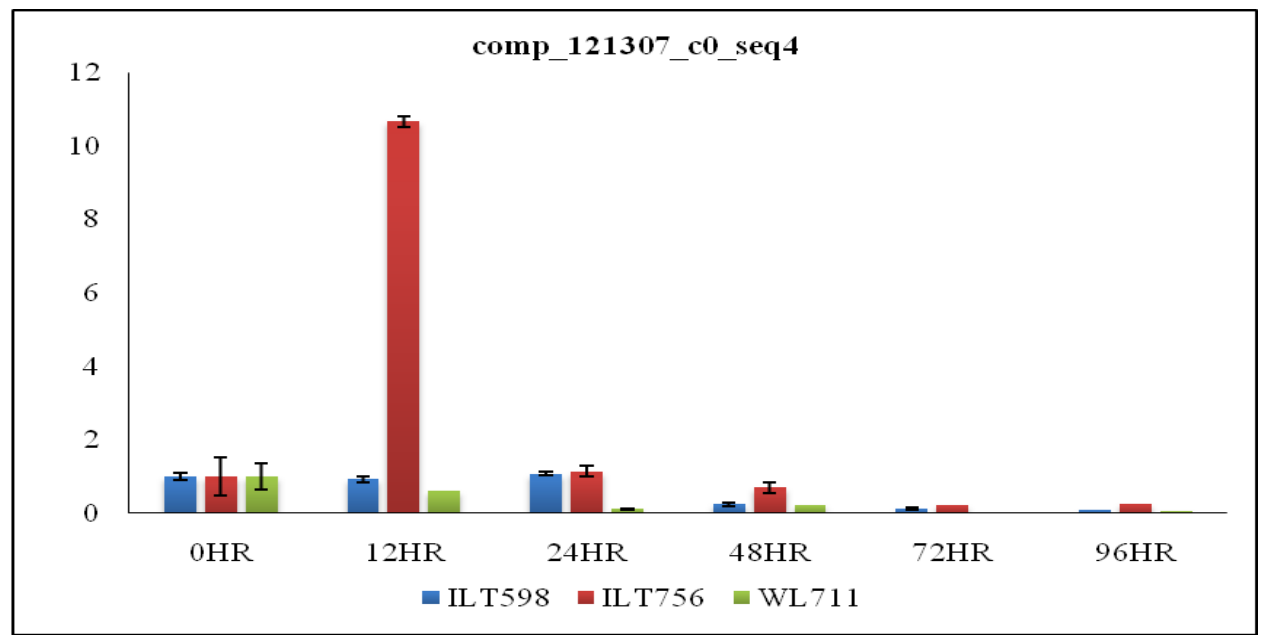

Fig.5 Gene folds expression (for stripe rust inoculated) at six different time interval in three parental lines IL T598, IL T756, and WL11 


\section{Acknowledgement}

I acknowledge to Dr Satinder Kaur as a Master degree advisor to give me a chance to explore my research experiences in her project during my master degree. I personally thankful to school of agriculture Biotechnology PAU Ludhiana for financial and technical support to carry out this research experiment

\section{References}

Aghaee, S.M., Singh, H. and Dhaliwal, H.S. (2000) $P h^{I}$ gene derived from Aegilops speltoides induces homoeologous chromosome pairing in wide crosses of Triticum aestivum. J Hered 91: 417421.

Alexandratos, N. and Bruinsma, J. World agriculture towards 2030/2050: the 2012 revision

Bansal, M. Kaur, S. Dhaliwal, H. S. Bains, N. S. Bariana, H. S. Chhuneja, P. Bansal, U. K. (2016) Mapping of Ae. umbellulata derived leaf and stripe rust resistance loci in wheat. Doi:10.1111/ppa.12549

Chen, P.D. Tsujimoto, H. and Gill, B.S. (1994) Transfer of PhI genes promoting homeologous, pairing From Triticum speltoides to common wheat.Theor Appl Genet 88:97-101.

Chen, P.D. Tsujimoto, H. and Gill, B.S. (1994) Transfer of $P h^{I}$ gene promoting homoeologous pairing from Triticum speltoides into common wheat and their utilization in alien genetic introgression. Theor Appl Genet 88: 97-101.

Cheng, Y. Zhang, H. Yao, J. Wang, X. Xu, J. Han, Q. Wei, G. Huang, L. and Kang, Z. (2012) Characterization of non-host resistance in broad bean to the wheat stripe rust pathogen BMC PLANT Biol: 96: 1471-2229.

Chhuneja, P. Kaur, S. Garg, T. Ghai, M.
Kaur, S. Prashar, M. Bains, N.S. Goel, R.K. Keller, B. Dhaliwal, H.S. and Singh, K. (2008) Mapping of adult plant stripe rust resistance genes in diploid A genome wheat species and their transfer to bread wheat. TheorAppl Genet 116:313-24.

Dangle, J.L. Dietrich, R.A. and Richberg, M.H. (1996) Death don't have no mercy: cell death programs in plantmicrobes interaction. Plant Cell 8:17931807.

Dhaliwal, H.S. Singh, H. Gill, K.S. and Randhawa, H.S. (1993) Evaluation and cataloguing of wheat germplasm for disease resistance and quality. In: Damania AB (ed) Biodiversity and wheat improvement. John Wiley \& Sons Pub: 123-140.

Flor, H. (1942) Inheritance of pathogenicity in Melampsora lini. Phytopathology 32:653-69.

Friebe, B. Jiang, J. Raupp, W.J. McIntosh, R.A. and Gill, B.S. (1996) Characterization of wheat-alien translocations conferring resistance to diseases and pests: current status. Euphytica 91:59-87.

Graham, R.D. McGrann, Philip, H. Smith, B.C. Mateos, G.R. Turnbull, N. ChamaCormack, R.M. Wessels, E. Agenbag, G. and Lesley, A. Boyd (2014) Genomic and genetics analysis of the wheat race-specific yellow rust resistance gene $\operatorname{Yr} 5$ doi: 10.7243/20502389-3-2.

Heath, C.M. 2000 Non host resistance and non-specific plant defences current openion in plant Biol 3: 315-319.

Jiang, J. Friebe, B. and Gill, B.S. (1994) Recent advances in alien gene transfer in wheat. Euphytica 73: 199-212.

Knott, D.R. (1989) the wheat rusts, breeding for Resistance. Springer Verlag, Berlin, Germany.

Knott, D.R. and Dvorak, J. (1981) Agronomic 
and quality characteristics of wheat lines with

Kuraparthy, V. Chhuneja, P. Dhaliwal, H.S. Kaur, S. Bowden, R.L. and Gill, B.S. (2007a) Characterization and mapping of cryptic alien introgression from Aegilops geniculata with novel leaf rust and stripe rust resistance genes Lr57 and Yr40 in wheat. Theor Appl Genet. 114:1379-89.

Macho, A.P. and Zipfel, C. (2014). Plant PRRs and the activation of innate immune signaling. Mol.Cell. 54:263272.

Marais, G.F. McCallum, B. Snyman, J.E. Pretorius, Z.A. and Marais, A.S. (2005) Leaf rust and stripe rust resistance genes Lr54 and Yr37 transferred to wheat from Aegilops kotschyi.Plant Breed .124:538-41.

McIntosh, R.A. Welling's, C.R. and Park, R.F. (1995) Wheat rusts: An atlas of resistance genes. CSIRO, Melbourne, Australia.

Nayar, B.N. and Bhardwaj, S.C. (1998) Management of wheat rusts in India. In: Upadhyay, R.K. Mukherjee, K.G. and Rajak, R.L. (Ed) IPM System in Agriculture. Vol.3 Cereals.

Sharma, H.C. and Gill, B.S. (1983) status of wide hybridization in wheat. Euphytica 32:117-31.

Singh, K. Ghai, M. Garg, M. Chhuneja, P. Kaur, P. Schnurbrsch, T. Keller, B. Dhaliwal, H.S.(2007b) An integrated molecular linkage map of diploid wheat based on a Triticum boeoticum $\mathrm{x} T$. monococcum RIL population. Theor Appl Genet 115: 301-312

Singh, K. Ghai, M. Garg, M. Chhuneja, P. Kaur, P. Schnurbusch, T. Keller, B. and Dhaliwal, H.S. (2007) An integrated molecular linkage map of diploid wheat based on a Triticum boeoticum X $T$. monococcum RIL population. TheorAppl Genet 115:301-12.

Stakman, E.C. Stewart, D.M. and Loegering, W.Q. (1962) Identification of physiological races of Puccinia recondita var. tritici. Miss Agri Expt Sta Sci J Series paper 4691.

Valkoun, J. and Hammer, K. and Erova, K. Dagmar and Bartoa, P. (1985). Disease resistance in the genus Aegilops L. stem rust, leaf rust, stripe rust and powdery mildew. Genet resour and crop evolution. 33: 133-153. 10.1007/BF01997267

Nath, J. McNay, J.W. Paroda, C.M. Gulati, S.C. (1983) Implication of Triticum searsii as the B genome donor B genome donor to wheat using DNA hybridizations. Biochem Genet 21: 74560

Gill, B.S. and Raupp, W.J. (1987) Direct genetic transfers from Aegilops squarrosa L. to hexaploid wheat. Crop Sci. 27:445-450.

https://en.wikipedia.org/wiki/ international wheat production

\section{How to cite this article:}

Shivendra Kumar, Satinder Kaur, Parveen Chhuneja, Mitaly Bansal, Indrajeet Singh Yadav. 2020. Fine Mapping and Expression Analysis of Stripe Rust Resistance Genes derived from Aegilops Geniculata. Int.J.Curr.Microbiol.App.Sci. 9(02): 2640-2653. doi: https://doi.org/10.20546/ijcmas.2020.902.301 